\title{
PERBANDINGAN HASIL PEMERIKSAAN PROTEIN URIN PADA IBU HAMIL TRIMESTER II BERDASARKAN USIA BERISIKO DAN USIA TIDAK BERISIKO SEBAGAI SKRINING PREEKLAMPSIA DI PUSKESMAS TARUMAJAYA KABUPATEN BEKASI
}

\author{
Ellis Susanti ${ }^{1)}$, *Siti Jumhati ${ }^{1)}$, Umi Jillah Mahabah' ${ }^{1)}$, \\ ${ }^{1}$ Program Studi Analis Kesehatan, Fakultas Kesehatan, Universitas Mohammad Husni Thamrin \\ Correspondence author: Siti Jumhati, jumhati1981@gmail.com, Jakarta, Indonesia
}

\begin{abstract}
ABSTRAK
Preeklampsia merupakan suatu penyakit yang ditandai dengan adanya hipertensi, oedema dan protein urin. Preeklampsia disebabkan oleh beberapa faktor salah satunya usia ibu yang ekstrim usia yang terlalu muda $<20$ tahun dan usia terlalu tua $>35$ tahun. Untuk mencegah terjadinya preeklampsia pada ibu hamil sebaiknya dilakukan tes skrining salah satunya pemeriksaan protein urin. Metode penelitian yang digunakan deskriptif dengan comperative study (studi perbandingan), dan teknik pengambilan sampling yaitu purposive sampling dengan jumlah sampel $40 \mathrm{ibu}$ hamil. Analisa data menggunakan uji MannWhitney dengan $\alpha=0,05$. Hasil analisis perbandingan hasil pemeriksaan protein urin pada ibu hamil trimester II berdasarkan usia berisiko dan usia tidak berisiko didapat kan $\mathrm{P}$ value $0,041<\mathrm{P}=0,05$, yang dapat disimpulkan bahwa ada perbedaan hasil pemeriksaan protein urin pada ibu hamil trimester II dengan usia tidak berisiko dan usia tidak berisiko
\end{abstract}

Kata Kunci : Preeklampsia, protein urin, usia berisiko dan dan usia tidak berisiko

\section{ABSTRACT}

Preeclampsia is a disease characterized by hypertension, edema and urinary protein. Preeclampsia is caused by several factors, one of which is extreme maternal age, too young $<20$ years and too old $>35$ years. To prevent preeclampsia in pregnant women, screening tests should be carried out, one of which is urine protein examination. The research method used is descriptive with a comparative study (comparative study), and the sampling technique is purposive sampling with a sample size of 40 pregnant women. Analysis of data using the Mann-Whitney test with $\alpha=0.05$. The results of the comparative analysis of the results of urine protein examination in second trimester pregnant women based on age at risk and age at risk were obtained $P$ value $0.041<P=0.05$, which can be concluded that there is differences in the results of urine protein examination in second trimester pregnant women with age not at risk and age not at risk

Keywords: Preeclampsia, urine protein, age at risk and age at risk 


\section{PENDAHULUAN}

Preeklampsia adalah penyakit dengan tanda-tanda Hipertensi, oedema dan protein urin akibat kehamilan, terutama pada komplikasi primigravida terjadi setelah usia gestasi 20 sampai 40 minggu (Siwi Elisabeth, 2015). Hal seperti ini juga disebut toxemia atau Pregnancy Induced Hypertension (PIH). Preeklampsia umumnya terjadi dalam trimester ketiga kehamilan, tetapi dapat juga pada timester kedua kehamilan (diatas 20 minggu) (Safitri, 2017).

Menurut World Health Organization (WHO) tahun 2012, salah satu penyebab kematian ibu dan janin adalah preeklamsia berat (PEB), angka kejadiannya berkisar antara 0,51\% - 38,4\%. Menurut WHO tahun 2015, Indonesia berada di peringkat keempat tertinggi untuk Angka Kematian Ibu (AKI) yang tercatat 126 per 100.000 kelahiran hidup dikawasan ASEAN dan peringkat keenam dikawasan SEAR (South East Asian Region). Banyak faktor penyebab AKI yang masih tinggi di Indonesia menurut Kemenkes RI diantaranya adalah perdarahan post partum (26,9\%), pre-eklampsia/ eklampsia (23\%), infeksi (11\%), komplikasi purpureum (8\%), trauma obstetrik (5\%), emboli obstetrik (8\%), aborsi (5\%) dan lain-lain (10,9\%). (Kemenkes RI, 2015)

Berdasarkan Laporan Kesehatan Provinsi Jawa Barat, kabupaten Bekasi merupakan salah satu kabupaten di Provinsi Jawa Barat yang masuk ke dalam sepuluh besar penyumbang AKI di provinsi Jawa Barat, yaitu dengan AKI pada tahun 2013 adalah 42 per 100.000 kelahiran hidup, tahun 2014 mengalami penurunan menjadi 30 per 100.000 kelahiran hidup, dan tahun 2015 menjadi 44 per 100.000 kelahiran hidup. Faktor penyebab kematian besar adalah karena perdarahan dan PEB (Preeklampsia Berat). (Dinkes Provinsi Jawa Barat, 2015)

Dalam penelitian Syifa dan Mariono (2015) di kabupaten Bekasi ditemukan bahwa penderita preeklampsia berat adalah berusia 20-35 tahun sebanyak 75\%, multigravida sebanyak $67,9 \%$ memiliki riwayat pre-eklampsia sebanyak 53,6\%. Tahun 2016 penyebab tertinggi kematian ibu di Bekasi dari 534 orang adalah Preeklampsia / eklampsia yaitu sebesar 30,90\% atau sebanyak 165 orang, sedangkan penyebab paling kecil adalah infeksi sebesar $4,87 \%$ atau sebanyak 26 orang.

Preeklampsia belum bisa diketahui secara pasti sampai saat ini, tetapi ada beberapa faktor yang mempengaruhi terjadinya preeklampsia salah satunya usia ibu yang ekstrim ( $<20$ tahun dan $>35$ tahun), karena wanita yang memiliki usia $<20$ tahun dan $>35$ tahun lebih rentan terkena preeklampsia. Selain itu ibu hamil yang berusia $>35$ tahun telah terjadi perubahan pada jalan lahir tidak lentur lagi sehingga lebih berisiko untuk terjadi preeklampsia (Novianti, 2015). Adanya perubahan-perubahan tersebut wanita hamil harus selalu waspada dan berhati-hati. Pada penelitian yang dilakukan Hajar Nur Fathur (2018) di RSUD 
Kota Bekasi didapatkan hasil bahwa penderita preeklampsia bedasarkan usia yang berisiko sebanyak 113 orang $(73 \%)$ dan tidak berisiko sebanyak 12 orang $(26,1 \%)$. Sehingga dalam upaya mencegah terjadinya preeklampsia pada ibu hamil sebaiknya dilakukan tes skrining berupa Body Massa Index (BMI), Mean Arterial Pressure (MAP), Roll over Test (ROT) dan pemeriksaan protein urin (Sulistyono, 2015).

Pada usia kehamilan trimester II, terjadi perubahan tekanan pada vena ginjal (tekanan vena renalis) yang semakin meningkat. Tekanan vena renalis yang meningkat akan menyebabkan proteinuria terutama pada posisi ortostatik sehingga terjadi perubahan ukuran sedikit lebih besar pada ginjal, Laju Filtrasi Glomerolus (GFR) terganggu sehingga protein yang merupakan molekul berukuran besar yang seharusnya tersaring dan digunakan oleh tubuh akan keluar bersama urin. Oleh karena itu, pemeriksaan protein urin pada trimester II penting dilakukan agar dapat mengindari timbulnya penyakit yang membahayakan ibu dan janin salah satunya preeklampsia (Idrus, 2009).

Dari data yang diperoleh dari rekam medis Puskesmas Tarumajaya Kabupaten Bekasi Tahun 2018 berkisar 56 ibu hamil (usia berisiko ada 17 ibu hamil dan usia tidak berisiko ada sebanyak 39 ibu hamil) yang mengalami preeklampsia ringan dan berkisar $17 \mathrm{ibu}$ hamil (usia berisiko ada 8 ibu hamil dan tidak berisiko ada sebanyak 9 ibu hamil) mengalami preeklampsia berat. Hal ini membuktikan bahwa kejadian preeklampsia merupakan masalah yang memerlukan penanganan untuk menjadi prioritas utama.

Berdasarkan permasalahan yang telah dipaparkan di atas, penulis tertarik ingin meniliti perbandingan hasil pemeriksaan protein urine pada ibu hamil trimester II bedasarkan usia berisiko dan tidak berisiko sebagai skrining preeklampsia di Puskesmas Tarumajaya Kabupaten Bekasi.

\section{METODE}

Penelitian ini dilakukan di Puskesmas Tarumajaya Kabupaten Bekasi. Waktu penelitian dilakukan pada bulan 24 Juli - 7 Agustus 2019. Populasi penelitian yaitu keseluruhan ibu hamil trimester II di Puskesmas Tarumajaya Kabupaten Bekasi dari tanggal 24 Juli - 7 Agustus 2019. Sampel yang digunakan adalah seluruh ibu hamil trimester ke II yang melakukan pemeriksaan protein urin di Puskesmas Tarumajaya Kabupaten Bekasi dari tanggal 24 Juli - 7 Agustus 2019. Sampel dihitung bedasarkan data ibu hamil usia berisiko di bulan Juni 2019 sebanyak 20 sampel Pasien ibu hamil trimester II diminta untuk mengisi kuesioner. Pengambilan spesimen dilakukan oleh pasien sendiri. Melakukan uji protein urin dengan menggunakan metode carik celup. 


\section{Hasil Pembahasan}

Responden adalah ibu hamil trimester II yang melakukan pemeriksaan di Puskesmas Tarumajaya Kabupaten Bekasi. Adapun karakteristik responden adalah sebagai berikut :

Tabel 1

Distribusi Karakteristik Responden di Puskesmas Tarumajaya Kabupaten Bekasi

\begin{tabular}{|c|c|c|c|c|}
\hline Variabel & $\mathbf{F}$ & $\%$ & $\begin{array}{c}\text { Protein } \\
(+)\end{array}$ & $\begin{array}{l}\text { Protein } \\
(-)\end{array}$ \\
\hline \multicolumn{5}{|l|}{ Usia : } \\
\hline Berisiko & 20 & 50 & 9 & 11 \\
\hline Tidak Berisiko & 20 & 50 & 3 & 17 \\
\hline \multicolumn{5}{|l|}{ Pendidikan : } \\
\hline SD & 9 & 22,5 & 3 & 6 \\
\hline SMP & 18 & 45 & 5 & 13 \\
\hline SMA & 13 & 32,5 & 4 & 9 \\
\hline Perguruan Tinggi & 0 & 0 & & 0 \\
\hline \multicolumn{5}{|l|}{ Status Pekerjaan : } \\
\hline Bekerja & 2 & 5 & 0 & 2 \\
\hline Tidak Bekerja & 38 & 95 & 12 & 26 \\
\hline \multicolumn{5}{|l|}{ Kehamilan Ke- : } \\
\hline $\mathrm{Ke}-1$ & 8 & 20 & 0 & 7 \\
\hline $\mathrm{Ke}-2$ & 12 & 30 & 2 & 10 \\
\hline $\mathrm{Ke}-3$ & 11 & 27,5 & 4 & 7 \\
\hline $\mathrm{Ke}-4$ & 6 & 15 & 4 & 2 \\
\hline $\mathrm{Ke}-5$ & 2 & 5 & 1 & 1 \\
\hline $\mathrm{Ke}-9$ & 1 & 2,5 & 1 & 0 \\
\hline \multicolumn{5}{|l|}{ Riwayat Penyakit : } \\
\hline Hipertensi & 9 & 22,5 & 7 & 2 \\
\hline Diabetes & 0 & 0 & 0 & 0 \\
\hline Ginjal & 1 & 2,5 & 1 & 0 \\
\hline Pembengkakan & 0 & 0 & 0 & 0 \\
\hline Riwayat Preeklampsia & 1 & 2,5 & 1 & 0 \\
\hline Normal & 29 & 72,5 & 3 & 26 \\
\hline Penyakit lainnya & 0 & 0 & 0 & 0 \\
\hline \multicolumn{5}{|l|}{ Umur Kehamilan : } \\
\hline $14-17$ Minggu & 8 & 20 & 1 & 7 \\
\hline $18-21 \mathrm{Minggu}$ & 9 & 22,5 & 2 & 7 \\
\hline $22-26$ Minggu & 23 & 57,5 & 9 & 14 \\
\hline
\end{tabular}

Berdasarkan tabel diatas dapat diketahui bahwa usia responden yang berisiko sebanyak 20 orang (50\%) dan usia responden yang tidak berisiko sebanyak 20 orang (50\%). Tingkat pendidikan responden yang terdiri dari SD dengan jumlah 10 orang (22,5\%), SMP dengan jumlah 17 orang (45\%) dan SMA dengan jumlah 13 orang (32,5\%). Dari 40 orang, 38 orang tidak bekerja atau sebagai ibu rumah tangga saja (95\%) dan yang bekerja hanya terdapat 2 orang (5\%). Pada kehamilan anak paling banyak mendominasi pada kehamilan anak ke-2 dengan jumlah 12 orang (30\%) dan anak ke-3 yaitu dengan jumlah 11 orang 
(27,5\%). Riwayat penyakit responden mayoritas normal dengan jumlah 29 orang (72,5\%) lalu dikuti hipertensi dengan jumlah 9 orang $(22,5 \%)$, kemudian penyakit ginjal 1 orang $(2,5 \%)$ dan riwayat preeklampsia 1 orang (2,5\%). Pada umur kehamilan paling mendominasi pada umur kehamilan 22 - 26 minggu ada 23 orang (57,5\%), setelah itu diikuti oleh umur kehamilan 18 - 21 minggu ada 9 orang $(22,5 \%)$ dan umur kehamilan 14 - 17 minggu ada 8 orang $(20 \%)$.

Setelah dilakukan penelitian dan didapatkan data hasil pemeriksaan protein urin terhadap 40 ibu hamil trimester II bedasarkan usia berisiko dan usia tidak berisiko periode 24 Juli - 7 Agustus 2019, didapatkan hasil penelitian yang disajikan dalam bentuk tabel distribusi frekuensi untuk analisis univariat dan dalam bentuk tabel Uji Mann - Whitney untuk hasil analisis bivariat.

Tabel 2.

Distribusi Frekuensi Antara Hasil Pemeriksaan Protein Urin Pada Ibu Hamil Trimester II Bedasarkan Usia

\begin{tabular}{cccccccc}
\hline \multirow{2}{*}{$\begin{array}{c}\text { Hasil } \\
\text { Protein }\end{array}$} & \multicolumn{2}{c}{ Usia Berisiko } & \multicolumn{2}{c}{ Usia Tidak Berisiko } & \multicolumn{2}{c}{ Total } \\
\cline { 2 - 5 } & \multicolumn{2}{c}{$(<20 \&>35$ tahun $)$} & \multicolumn{2}{c}{$20-35$ tahun } & & \multirow{2}{*}{$\%$} \\
\cline { 2 - 5 } & $\mathrm{F}$ & $\%$ & $\mathrm{~F}$ & $\mathbf{F}$ & & $\%$ \\
\hline Negatif & 11 & 55 & 17 & 85 & 28 & 70 \\
\hline Positif & 9 & 45 & 3 & 15 & 12 & 30 \\
\hline Total & 20 & 100 & 20 & 100 & 40 & 100 \\
\hline
\end{tabular}

Berdasarkan tabel 2 dari total usia yang berisiko yang berjumlah 20 ibu hamil trimester II, menunjukkan hasil pemeriksaan protein urin negatif berjumlah 11 (55\%) dan yang positif berjumlah 9 (45\%). Kemudian dari total usia tidak berisiko yang berjumlah 20 ibu hamil trimester II, menunjukkan hasil pemeriksaan protein negatif berjumlah 17 (85\%) dan yang positif berjumlah $3(15 \%)$.

Data primer yang didapat $20 \mathrm{ibu}$ hamil trimester II usia berisiko dan $20 \mathrm{ibu}$ hamil usia tidak berisiko di Puskesmas Tarumajaya Kabupaten Bekasi Periode 24 Juli - 7 Agustus 2019. Pada penelitian ini variabel yang akan dianalisis adalah perbedaan hasil protein urin bedasarkan usia berisiko dan usia tidak berisiko. Jenis uji yang digunakan tergantung dari hasil uji normalitas data. Jika data berdistribusi normal maka data diolah dengan analisis bivariat menggunakan Uji Independent T-test tetapi jika data terdistribusi tidak normal maka uji yang digunakan adalah Uji Mann-Whitney.

Uji normalitas yang digunakan adalah Uji Shapiro-Wilk. Data dikatakan tedistribusi normal jika P value $>0,05$. Hasil uji dapat dilihat pada tabel dibawah ini : 
Tabel 3.

Hasil Uji Normalitas Protein Urin Bedasarkan Usia

\begin{tabular}{llll}
\hline & \multicolumn{3}{c}{ Shapiro-Wilk } \\
\cline { 2 - 4 } & Statistik & Df & Sig \\
\hline Hasil Protein & 0,576 & 40 & 0,000 \\
\hline
\end{tabular}

Dari uji normalitas didapatkan data tidak berdistribusi normal karena $\mathrm{P}$ value yang didapat 0,000 atau $<0,05$ sehingga uji yang dilakukan selanjutnya menggunakan analisis bivariat Uji Mann-Whitney.

Tabel 4.

Hasil Uji Mann - Whitney Antara Hasil Pemeriksaan Protein Urin Pada Ibu Hamil Trimester II Bedasarkan Usia Berisiko dan Usia Tidak Berisiko

\begin{tabular}{llll}
\hline \multicolumn{2}{c}{ Usia } & N & Signifikan \\
\hline \multirow{4}{*}{ Hasil Protein Urin } & Berisiko & 20 & \\
\cline { 2 - 4 } & Tidak Berisiko & 20 & 0,041 \\
\cline { 2 - 4 } & Total & 40 & \\
\hline
\end{tabular}

Mann-Whitney Test

Bedasarkan uji tersebut diperoleh hasil sig (2-tailed) sebesar 0,041 atau <0,05. Dari hasil analisis statistik Uji Mann - Whitney tersebut maka dapat dikatakan bahwa Ho ditolak yang berarti ada perbedaan hasil pemeriksaan protein urin pada ibu hamil trimester II dengan usia berisiko dan usia tidak berisiko.

Dari penelitian ini diketahui bahwa ibu hamil trimester II yang melakukan pemeriksaan di Puskesmas Tarumajaya Kabupaten Bekasi sebanyak 40 responden berdasarkan tabel 1 menunjukkan ibu hamil yang berisiko sebanyak 20 responden (50\%) didapatkan protein urin 9 responden positif dan 11 responden negatif sedangkan ibu hamil usia yang tidak berisiko sebanyak 20 responden (50\%) didapatkan protein urin 3 responden positif dan 17 responden negatif. Dari pendidikan responden mayoritas SMP sebanyak 18 responden (45\%) didapatkan protein urin 5 responden positif dan 13 responden negatif, lalu diikuti berpendidikan jenjang SMA sebanyak 13 responden (32,5\%) didapatkan protein urin 4 responden positif dan 9 responden negatif, serta berpendidikan SD sebanyak 9 responden $(22,5 \%)$ didapatkan protein urin 3 responden positif dan 6 responden negatif. Dari hasil yang didapat menunjukkan paling banyak yang terindikasi proteinuria pada berpendidikan rendah, dilihat dari gambaran tingkat pendidikan pada responden hanya berbeda sedikit dengan gambaran tingkat pendidikan di Kecamatan Tarumajaya yang mayoritas juga penduduknya berpendidikan rendah yaitu ada sekitar 66,15\% hanya tamat SD dan SMP (data profil Kecamatan Tarumajaya, 2015). 
Teori pendidikan mengatakan bahwa pendidikan adalah suatu kegiatan atau usaha untuk meningkatkan kepribadian serta kedewasaan. Semakin banyak pendidikan yang didapat seseorang, maka kedewasaannya semakin matang, mereka mudah menerima dan memahami suatu informasi yang positif (Julianti, 2014). Pendidikan secara tidak langsung berpengaruh dalam dalam menentukkan dan mengambil sebuah keputusan. Dengan tingginya tingkat pendidikan seorang wanita diharapkan semakin meningkat juga pengetahuan dalam mengantisipasi kesulitan kehamilan dan persalinan sehingga termotivasi untuk melakukan pengawasan kehamilan secara teratur. Namun, pendidikan yang dimiliki oleh seseorang belum menjamin untuk menderita atau tidak menderitanya seseorang tersebut pada suatu penyakit tertentu, hasil ini sesuai dengan penelitian dari Nuryani (2013).

Pada karakteristik responden dalam status pekerjaan sebagian besar responden tidak bekerja dengan jumlah 38 orang (95\%) didapatkan protein urin 12 responden positif dan 26 responden negatif dan hanya terdapat 2 orang yang bekerja (5\%) didapatkan protein urin dengan tidak ada responden yang positif dan 2 responden negatif. Dari hasil yang didapat menyatakan bahwa lebih banyak responden yang menjadi ibu rumah tangga atau tidak bekerja, hal tersebut kemungkinan hasil protein urin yang didapat bukan dari aktivitas bekerja melainkan dari kehamilannya yang akan membuat ibu hamil mudah merasa cepat lelah disebabkan kurangnya zat besi dalam tubuh serta adanya stress berat.

Aktvitas pekerjaan memiliki dampak terhadap peredaran darah dan kerja otot. Perubahan darah pada ibu hamil terjadi seiring dengan pertambahnya usia kehamilan, hal ini terjadi seiring dengan bertambahnya usia kehamilan, hal ini terjadi karena pembesaran dari uterus. Bertambahnya usia kehamilan berdampak semakin bertambahnya kerja jantung untuk memenuhi kebutuhan selama hamil. Aktivitas pekerjaan dapat dilakukan selama tidak terlalu berat, sehingga kelancaran peredaran darah tetap terjaga dan ibu hamil bisa terhindar dari preeklampsia (Yusrawati. dkk, 2013)

Kehamilan ibu paling banyak mayoritas pada kehamilan yang ke-2 ada 12 responden (30\%) didapatkan protein urin 2 responden positif dan 10 responden negatif, lalu diikuti pada kehamilan yang ke-3 ada 11 responden $(27,5 \%)$ didapatkan protein urin 4 responden positif dan 7 responden negatif, kehamilan yang ke-1 ada 8 responden (20\%) didapatkan protein urin tidak ada responden untuk yang positif dan 7 responden negatif, kehamilan yang ke-4 ada 6 responden (15\%) didapatkan protein urin 4 responden positif dan 2 responden negatif, kehamilan yang ke-5 ada 2 responden (5\%) didapatkan protein urin 1 responden positif dan untuk negatif tidak ada responden dan kehamilan yang ke-9 ada 1 orang $(2,5 \%)$ didapatkan 1 responden positif dan untuk negatif tidak ada responden. Pada penelitian ini ditemukan paling banyak proteinuria dijumpai pada multigravida daripada primigravida, menurut (Bobak, 2014) pada multigravida disebabkan karena terlalu sering rahim teregang saat kehamilan dan terjadi penurunan 
angiotensin, renin dan aldosteron sehingga dapat dijumpai adanya proteinuria, hipertensi, dan oedema yang dapat mengindikasi preeklampsia.

Pada umumnya preeklampsia lebih sering terjadi pada kehamilan pertama dibandingkan dengan kehamilan berikutnya. Hal ini disebabkan karena pada kehamilan pertama pembentukkan blocking antibody terhadap antigen plasenta tidak sempurna, yang semakin sempurna pada kehamilan berikutnya. Secara teori, primigravida lebih berisiko untuk mengalami preeklampsia daripada multigravida karena preeklampsia biasanya timbul pada wanita yang pertama kali terpapar vilus korion. Hal ini terjadi karena pada wanita tersebut mekanisme imunologik pembentukkan blocking antibody yang dilakukan oleh HLAG (Human Leukocyte Antigen $G$ ) terhadap antigen plasenta belum terbentuk secara sempurna, sehingga proses implantasi trofoblas ke jaringan desidual ibu menjadi terganggu (Novianti, 2016)

Keadaan ibu hamil yang melakukan pemeriksaan di Puskesmas Tarumajaya Kabupaten Bekasi hampir seluruh responden yaitu normal sebanyak 29 responden (72,5\%) didapatkan protein urin 3 responden positif dan 26 responden negatif, lalu mengalami hipertensi sebanyak 9 responden $(22,5 \%)$ didapatkan protein urin 7 responden positif dan 2 responden negatif dan sebagian kecil mengalami penyakit ginjal sebanyak 1 responden (2,5\%) didapatkan protein urin 1 responden positif dan negatif tidak ada responden, riwayat preeklampsia sebanyak 1 responden $(2,5 \%)$ didapatkan protein urin 1 responden positif dan untuk negatif tidak ada responden. Dari hasil yang didapat protein positif paling banyak pada responden yang mempunyai riwayat penyakit hipertensi lalu disusul dengan normal, riwayat preeklampsia serta penyakit ginjal. Hal tersebut memungkinkan karena kurangnya kesadaran ibu dalam melakukan antenatal care untuk pencegahan pada kehamilan sejak dini, sehingga ibu yang mempunyai riwayat penyakit tersebut dapat memungkinkan membahayakan ibu dan janin. Pada ibu hamil antenatal care itu penting karena dapat mengurangi komplikasi sejak dini yang akan mempengaruhi kehamilan.

Riwayat penyakit hipertensi merupakan salah satu faktor yang dihubungkan dengan preeklampsia. Hipertensi atau penyakit darah tinggi adalah gangguan pembuluh darah yang mengakibatkan suplai oksigen dan nutrisi yang dibawa oleh darah terhambat sampai ke jaringan tubuh yang membutuhkannya. Bila ibu sebelumnya sudah menderita hipertensi maka keadaan ini akan memperberat keadaan ibu. Sehingga bagi ibu yang hamil dengan memiliki riwayat hipertensi harus mewaspadai kemungkinan tejadinya preeklampsia dengan cara melakukan antenatal care yang optimal (Widyaningrum, 2012).

Riwayat preeklampsia pada kehamilan merupakan salah satu faktor pendukung terjadinya preeklampsia pada kehamilan. Riwayat preekampsia mempunyai resiko yang lebih tinggi tejadinya preeklampsia dibandingkan Ibu hamil tanpa riwayat preeklampsia, hal ini dikarenakan ibu hamil dengan riwayat 
preeklampsia terdapat kecenderungan diwariskan, preeklampsia sebagai penyakit yang diturunkan ke anak atau saudara perempuan (Fatkhiyah, dkk., 2016).

Kehamilan dapat mempengaruhi timbulnya penyakit ginjal salah satunya diabetes mellitus pada seseorang. Sejak kehamilan terjadilah perubahan tingkat kabohidrat dalam tubuh ibu yang diperlukan untuk energi lebih dari biasanya bagi pertumbuhan janin. Namun asupan kabohidrat yang meningkat dapat membuat hormon insulin dalam tubuh tidak mencukupi. Peran hormon ini yaitu untuk mengendalikan kadar gula dalam darah yang diubah kabohidrat. Akibatnya terjadilah penimbunan kadar gula yang menyebabkan kenaikan kadar gula darah. Diabetes bawaan maupun diabetes yang didapat selama hamil bisa berakibat buruk bagi kehamilan dan berisiko terjadinya preeklampsia (Astuti, 2015).

Ibu hamil trimester II yang periksa kehamilan sebagian pada usia kehamilan 22 sampai 26 minggu terdapat 23 responden (57,5\%) didapatkan protein urin 9 responden positif dan 14 responden negatif, sedangkan ibu hamil usia kehamilan 18 sampai 21 minggu berjumlah 9 responden $(22,5 \%)$ didapatkan protein urin 2 responden positif dan 7 responden negatif, dan ibu hamil usia kehamilan 14-17 minggu berjumlah 8 responden (20\%) didapatkan protein urin 1 responden positif dan 7 responden negatif. Dari hasil yang didapat paling banyak protein positif pada ibu hamil yang mempunyai usia kehamilan lebih dari 20 minggu terdapat 9 yang positif, hal tersebut dikarenakan pada usia kehamilan $>20$ minggu dimana ibu hamil lebih sering mengalami komplikasi serius yang dapat berkembang selama kehamilan yang ditandai dengan adanya hipertensi $>160 / 110 \mathrm{mmHg}$, oedema dan protein urin (Pujiningsih, 2010).

Pada analisis univariat yang terdapat pada tabel 2 terdapat 20 ibu hamil trimester II yang melakukan pemeriksaan protein urin yang berusia berisiko, menunjukkan hasil pemeriksaan protein negatif berjumlah $11(55 \%)$ dan yang positif berjumlah 9 (45\%), kemudian terdapat ibu hamil trimester II yang melakukan pemeriksaan urin yang usia tidak berisiko, menunjukkan hasil pemeriksaan protein negatif berjumlah 17 (85\%) dan yang positif berjumlah 3 (15\%). Hal tersebut membuktikan bahwa dari 40 ibu hamil, yang kehamilan bermasalah karena proteinuria terdapat 9 responden $(45 \%)$ pada usia berisiko dan terdapat 3 responden (15\%) pada usia tidak berisiko. Menurut Idrus (2009) proteinuria terbentuk dari pembentukkan urin dalam glomerulus, apabila filtrasi glomerulus mengalami kebocoran yang hebat, molekul protein besar akan terbuang dalam urin sehingga menyebabkan proteinuria, beberapa keadaan yang dapat menyebabkan proteinuria adalah penyakit ginjal, hipertensi, keracunan kehamilan atau pre-eklampsia dan infeksi saluran kemih. Adanya protein urin dapat menyebabkan preeklampsia. Preeklampsia adalah suatu penyakit yang ditandai dengan adanya Hipertensi, oedema dan protein urin akibat kehamilan (Siwi Elisabeth, 2015). 
Pada tabel 3 dilakukan uji statistik untuk mencari normalitas dengan uji Shapiro-Wilk didapatkan hasil P value 0,000 atau $<0,05$ sehingga data tidak berdistribusi normal. Dari data tidak berdistribusi normal maka dilanjutkan dengan uji Mann-Whitney untuk mengetahui adanya perbedaan hasil protein urin pada ibu hamil trimester II dengan usia berisiko dan usia tidak berisiko, pada tabel 4 dari uji Mann-Whitney dapat dilihat $\mathrm{P}$ value 0,041 (sig:p<0,05), yang artinya Ho ditolak yang berarti ada perbedaan hasil pemeriksaan protein ibu hamil trimester II dengan usia berisiko dan usia tidak berisiko. Hal tersebut menunjukkan adanya kelibatan faktor usia dalam mempengaruhi hasil pemeriksaan protein pada ibu hamil trimester II dan sesuai dengan tabel 2 yang telah dibahas yaitu kejadian yang dimungkinkan berhubungan dengan usia. Hal tersebut sesuai dengan pernyataan (Manuaba, 2010) yang mengungkapkan bahwa dimana usia optimal untuk kehamilan adalah 20 -35 tahun, sedangkan usia yang berisiko terdapat pada usia ekstrim, yaitu pada remaja belasan tahun ( $<20$ tahun) atau pada wanita yang berumur lebih dari 35 tahun yang dapat menyebabkan preeklampsia. Usia dibawah 20 tahun bukan masa yang baik untuk hamil karena organorgan reproduksi belum sempurna. Hal ini tentu akan menyulitkan proses kehamilan dan persalinan, sehingga wanita hamil dengan usia kurang dari 20 tahun insiden preeklampsia/ eklampsia lebih dari 3 kali lipat diduga karena adanya suatu imunologi disamping endokrin dan genetik. Selain itu ibu hamil yang berusia lebih dari 35 tahun telah terjadi perubahan pada jalan lahir tidak lentur lagi dan hipertensi yang diperberat sehingga lebih berisiko untuk terjadi pre-eklampsia (Novianti, 2015). Adanya protein dalam urin bisa dijumpai pada ibu hamil yang sehat atau setelah senam hamil, urin yang pekat, atau stress dan emosi, dan bisa juga infeksi saluran kemih (Idrus, 2009).

Hasil analisis bivariat pada tabel 4 menunjukkan bahwa faktor usia dapat mempengaruhi hasil pemeriksaan protein urin pada ibu hamil, hasil ini sesuai dengan penelitian yang dilakukan oleh (Rohmah, Hajar Nur Fathur, 2018), yang menurutnya faktor-faktor yang dapat meningkatkan atau mempengaruhi hasil protein urin dalam kehamilan adalah usia baik itu usia berisiko dan usia tidak berisiko.

\section{SIMPULAN}

1. Hasil persentase pemeriksaan protein urin yang berusia berisiko ( $<20$ tahun dan $>35$ tahun), protein urin negatif sebesar $55 \%$ dan yang positif sebesar $45 \%$, sedangkan untuk usia tidak berisiko (20 - 35 tahun), protein urin negatif sebesar $85 \%$ dan yang positif sebesar $15 \%$.

2. Ada perbedaan antara hasil pemeriksaan protein urin pada ibu hamil trimester II dengan usia berisko dan usia tidak berisiko $(\mathrm{p}=0,041<0,05)$. 


\section{UCAPAN TERIMA KASIH}

Penulis mengucapkan terima kasih kepada Prodi D III Analis Kesehatan Universitas MH Thamrin berperan serta dalam penelitian ini.

\section{DAFTAR PUSTAKA}

1. Astuti, Sri Puji., Faktor-faktor Yang Berhubungan Dengan Kejadian Preeklampsia Kehamilan Di Wilayah Kerja Puskesmas Pamulang Kota Tangerang Selatan Tahun 2014 - 2015, Skripsi, Fakultas Kedokteran dan Ilmu Kesehatan UIN Syarif Hidayatullah Jakarta, 2015.

2. Bobak., Buku Ajar Keperawatan Maternitas, Jakarta : EGC, 2014.

3. Dahlan, M.Sopiyudin., Statistika Untuk Kedokteran Kesehatan Edisi 4, Salemba Medika, Jakarta, 2009.

4. Depkes RI. Profil Kesehatan Indonesia, Departemen Republik Indonesia, Jakarta, 2009).

5. Fathonah, Siti., Gizi \& Kesehatan untuk Ibu Hamil, Erlangga, Jakarta, 2016.

6. Fatkhiyah, Natiqotul, dkk., Determinan Maternal Kejadian Preeklampsia, Tegal, 2016.

7. Gandasoebrata, R., Penuntun Laboratorium Klinik, Dian Rakyat, Jakarta, 2010.

8. Gunawan S., Reproduksi Kehamilan dan Persalianan, CV Graha, Jakarta, 2010.

9. Hutahaean, Serri., Perawatan Antenatal, Salemba Medika, Jakarta, 2013.

10. Idrus, dkk., Ilmu Penyakit Dalam Jilid II, Interna Publishing, Jakarta, 2009.

11. Irianti, Bayu., dkk., Asuhan Kehamilan Berbasis Bukti Paradigma Badu Dalam Asuhan Kebidanan, Sagung Seto, 2015.

12. Julianti, Neneng., Faktor-faktor yang Berhubungan Dengan Kejaidan Preeklampsia Berat Pada Ibu Hamil Trimester II Di RSUD Kota Bekasi Tahun 2014., 2014.

13. Kementerian Kesehatan Republik Indonesia, Jakarta, 2015.

14. Manuaba, I.G. B, Ilmu Kebidanan, Penyakit Kandungan dan Keluarga dan Berencana Untuk Pendidikan Bidan, EGC, Jakarta, 2010.

15. Mochtar, R., Sinopsis Obstetri Jilid II, EGC, Jakarta, 2012.

16. Novianti, Hinda., Pengaruh Usia dan Paritas Terhadap Kejadian Pre Eklampsia di RSUD Sidoarjo, Surabaya, 2016.

17. Nuryani. dkk., Hubungan Pola Makan, Sosial Ekonomi, Antenatal Care dan Karakteristik Ibu Hamil dengan Kasus Preeklampsia di Kota Makassar, Jurnal Media Gizi Masyarakat Indonesia, 2013.

18. Pujiningsih, Sri., Permasalahan Kehamilan yang Sering Terjadi, Suka Buku, Jakarta, 2010.

19. Rohmah, Hajar Nur Fathur., Faktor-Faktor yang Berhubungan Dengan Kejadian Preeklampsia Berat Pada Ibu Hamil Trimester III Di RSUD Kota Bekasi 2018, Jakarta, 2018.

20. Ronald H.S., Pedoman \& Perawatan Kehamilan Sehat \& Menyenangkan, Nuansa Aulia, Bandung, 2011.

21. Safitri, Anita. dkk., Hubungan Graviditas Dengan Kejadian Preeklampsia Di Rumah Sakit Umum Dewi Sartika Kendari Provinsi Sulawesi Tenggara Tahun 2016, Politeknik Kesehatan Kendari, 2017.

22. Siwi, Walyani Elisabeth, Perawatan Kehamilan dan Menyusui Anak Pertama, Pustaka Baru Press, Yogyakarta, 2015.

23. Sulistyawati, Ari., Asuhan Kebidanan pada Masa Kehamilan, Salemba Medika, Jakarta, 2011.

24. Sulistyono, Agus., Preeklampsia,Tim Penakib, Surabaya, 2015.

25. WHO. Global Maternal Mortality Rate, World Health Organization, 2015.

26. Widyaningsih, Siti., Hubungan Antara Konsumsi Makanan Dengan Kejadian Hipertensi Pada Lansia, Skipsi, Fakultas Kesehatan Masyarakat Universitas Jember, 2012.

27. Yusrawati. dkk, Faktor Resiko Individual Pada Preeklampsia Pada RSUP Dr Djamil Padang, Fakultas Kedokteran Universitas Andalas, Padang, 2013.

Open Journal System (OJS): journal.thamrin.ac.id

http://journal.thamrin.ac.id/index.php/anakes/issue/view/35 